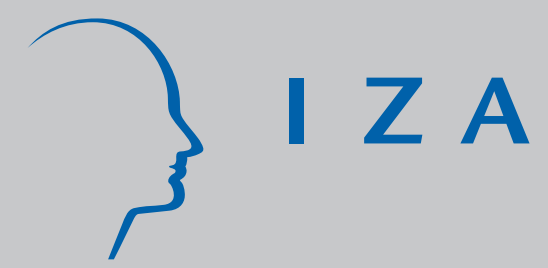

IZA DP No. 7320

Skill-Biased Technological Change and Skill-Enhancing Trade in Turkey: Evidence from Longitudinal Microdata

Ilina Srour

Erol Taymaz

Marco Vivarelli

March 2013

Forschungsinstitut zur Zukunft der Arbeit Institute for the Study of Labor 


\title{
Skill-Biased Technological Change and Skill-Enhancing Trade in Turkey: Evidence from Longitudinal Microdata
}

\author{
Ilina Srour \\ Università Cattolica del Sacro Cuore \\ Erol Taymaz \\ Middle East Technical University \\ Marco Vivarelli \\ Università Cattolica del Sacro Cuore, \\ SPRU, University of Sussex and IZA
}

Discussion Paper No. 7320

March 2013

\author{
IZA \\ P.O. Box 7240 \\ 53072 Bonn \\ Germany \\ Phone: +49-228-3894-0 \\ Fax: +49-228-3894-180 \\ E-mail: iza@iza.org
}

\begin{abstract}
Any opinions expressed here are those of the author(s) and not those of IZA. Research published in this series may include views on policy, but the institute itself takes no institutional policy positions. The IZA research network is committed to the IZA Guiding Principles of Research Integrity.

The Institute for the Study of Labor (IZA) in Bonn is a local and virtual international research center and a place of communication between science, politics and business. IZA is an independent nonprofit organization supported by Deutsche Post Foundation. The center is associated with the University of Bonn and offers a stimulating research environment through its international network, workshops and conferences, data service, project support, research visits and doctoral program. IZA engages in (i) original and internationally competitive research in all fields of labor economics, (ii) development of policy concepts, and (iii) dissemination of research results and concepts to the interested public.
\end{abstract}

IZA Discussion Papers often represent preliminary work and are circulated to encourage discussion. Citation of such a paper should account for its provisional character. A revised version may be available directly from the author. 


\section{ABSTRACT \\ Skill-Biased Technological Change and Skill-Enhancing Trade in Turkey: Evidence from Longitudinal Microdata}

This paper explores the causes of skill-based employment differentials within the Turkish manufacturing sector over the period 1980-2001. Turkey is taken as an example of a developing economy that, in that period, had been technologically advancing and becoming increasingly integrated with the world market. The empirical analysis is performed at firm level within a dynamic framework using a two-equation model that depicts the employment trends for skilled and unskilled workers separately. In particular, the System Generalized Method of Moments (GMM-SYS) procedure is applied to a panel dataset comprised of 17,462 firms. Our results confirm the theoretical expectation that developing countries face the phenomena of skill-biased technological change and skill-enhancing technology import, both leading to increasing the employment gap between skilled and unskilled workers. In particular, strong evidence of a relative skill bias emerges: both domestic and imported technologies increase the demand for skilled labor 5 to 6 times more than the corresponding demand for the unskilled labor. Finally, "learning by export" also appears to have a skill biased impact, but to a lesser extent.

JEL Classification: F16, O33

Keywords: skill-biased technological change, technology transfer, panel data, GMM-SYS

Corresponding author:

Marco Vivarelli

Facoltà di Economia

Università Cattolica

Via Emilia Parmense 84

29122 Piacenza

E-mail: marco.vivarelli@unicatt.it 


\section{INTRODUCTION}

Many developing countries (DCs) in the 1980's underwent structural changes, where they moved from import substitution to liberalization and export-oriented strategies. Opening their doors to international trade, these countries were faced with two major growth effects. On the one hand, liberalization has involved a static effect pertaining to inter-sectoral transfer of resources, mainly due to changes in the relative price structure. On the other hand, trade openness has fostered a dynamic effect emerging from the productivity growth due to increased exposure of local firms to competition (both foreign and domestic), increased technological imports embodied in capital and intermediate goods, and to the transfer of knowledge through licensing, patents and other rights (see Rodrik, 1995).

However, these productivity gains were coupled with a growing gap between the employment of skilled and unskilled workers. The standard Heckscher Ohlin and Stopler Samuelson predictions that trade liberalization would lead to egalitarian effects in developing countries have not been supported by empirical evidence. In this respect, the skill-biased technological change (SBTC) hypothesis is better able to describe the reality of shifting relative employment demand towards more skilled labor.

This paper explores the existence of skill-biased employment differentials within the Turkish manufacturing sector through examining the determinants of skill bias of employment over time, in both relative and absolute terms. Within this context, the conjecture is that technological change, especially skill-enhancing technological import, plays a significant role in raising demand for skilled workers, and thus contributes to increasing the employment gap between skilled and unskilled labor. Turkey presents itself as a suitable candidate for testing the argument of skill-biased technological change. It is a middle-income country with significant trade flows with developed countries, especially the EU; therefore, it relies on technology import as a main source for technological upgrading. In addition, during the 1980's Turkey underwent a process of trade liberalization, and shifted from its prior protectionist model of heavy state intervention, whereby it transformed from a rather closed (import-substitution) economy to a much more open (exportoriented) economy. According to the openness indicator of the World Bank Development Indicators, Turkey's openness increased from around 10\% in the 1960 's to about $40 \%$ in the period between 1980 and 2000 and has remained since on a level of about 50\% (Elitok and Straubhaar, 2010).

The novelty of this study in comparison with previous empirical literature on the subject (see Section 2) is that it is performed at firm level within a dynamic framework using a two-equation model that depicts the employment trends for skilled and unskilled workers separately. More specifically, it allows for understanding the forces driving the movements in employment of both types of workers. In fact, a positive shift of the skill-ratio could be the result of the reduction of unskilled workers only, the increase of skilled workers only, a faster increase in the numbers of skilled workers, or a combination of these movements. A single equation framework cannot capture these different dynamics; therefore, having two equations can provide a more thorough understanding of the nature of the skill-bias. In particular, the System Generalized Method of 
Moments (GMM-SYS) procedure is applied to a detailed panel of Turkish manufacturing firms (Annual Manufacturing Industry Statistics by the Turkish Statistical Institute, TurkStat), comprised of 17,462 firms over the period between 1980 and 2001.

The remainder of the paper is organized as follows: Section 2 surveys existing literature on the quantitative and qualitative employment impact of technology and analyses trade-based and technology-based explanations for the skill gap in the context of developing countries. Section 3 describes the data and related methodological issues. Section 4 provides some descriptive information regarding the structural adjustment program in Turkey, the state of manufacturing employment, and the technological upgrading that the country has undergone. Section 5 presents the empirical model and the econometric specification, then discussing the results obtained. Section 6 concludes with some final remarks.

\section{SURVEY OF THE LITERATURE}

\subsection{QuANTITATIVE AND QUALITATIVE EMPLOYMENT IMPACT OF TECHNOLOGY}

The conventional wisdom in economic theory states that technological unemployment is a temporary circumstance, which can be automatically compensated by market force mechanisms that work to reintegrate the employees who had lost their jobs (Vivarelli, 2013). These mechanisms came to be known as the "compensation theory", using the terminology presented by Marx in his discussions on large-scale industry and the introduction of machinery (see Marx 1961: Chap. 15). Six compensation mechanisms work to offset technology's labor-saving effects through: (1) additional employment in the capital goods sector where new machines are being produced, (2) decreases in prices resulting from lower production costs on account of technological innovations, (3) new investments made using extra profits due to technological change, (4) decreases in wages resulting from price adjustment mechanisms and leading to higher levels of employment, (5) increases in income resulting from redistribution of gains from innovation, and (6) new products created using new technologies (for a detailed analysis see Vivarelli, 1995; Pianta, 2005).

However, measuring the extent and actual effectiveness of these compensation mechanisms and assessing the final quantitative impact of technology on overall employment is not a straightforward exercise and has long been a subject of a controversial debate among economists (see Vivarelli, 1995, 2011 and 2013). In particular, low demand and capital/labor substitution elasticities, attrition, pessimistic expectations and delays in investment decisions may involve that compensation can only be partial.

The discourse on compensation mechanisms and their functioning has often taken place within the context of developed countries. In fact, their validity becomes even more questionable in the DCs, which are mainly passive recipients of technologies from advanced countries ${ }^{1}$.

\footnotetext{
${ }^{1}$ For examples on the ineffectiveness of compensation mechanisms in developing countries, see Karaomerlioglu and Ansal, 2000. They explain for instance that the first compensation mechanism concerned with employment in the capital goods sector is mostly inexistent in developing countries since they generally import their technologies rather than produce them locally. Therefore, the application of new technologies
} 
Apart from the quantitative impact of technology on the levels of employment, a stream of literature has shown that the relationship between technology and employment has a qualitative aspect as well, giving rise to the notion of Skill Biased Technological Change (SBTC). The concept of SBTC, first developed by Griliches (1969) and Welch (1970), is based on the hypothesis of capitalskill complementarity, and suggests that employers' increased demand for skilled workers is driven by new technologies that are penetrating into modernized industries, and which only workers with a higher level of skill can operate (Machin, 2003).

The literature on SBTC remains mainly empirical, where many studies indicate that SBTC has gained momentum during the past three decades due to the surge in information technology and spread in computers (Pianta, 2005). The first to explore SBTC empirically were Berman, Bound and Griliches (1994) who provided evidence for the existence of strong correlations between within industry skill upgrading and increased investment in both computer technology and R\&D in the U.S. manufacturing sector between 1979 and 1989. Autor, Katz and Krueger (1998) also show that the spread of computer technology in the US since 1970 can in fact explain as much as 30 to 50 percent of the increase in the growth rate of relative demand for skilled labor ${ }^{2}$. Additionally, Machin and Van Reenen (1998) provide evidence of SBTC through performing a cross-country study on seven OECD countries and assert a positive relation between $R \& D$ expenditure and relative demand for skilled workers.

\subsection{Trade-BASEd Vs. TeChnology-BASEd ExPlanations FoR the SKILl GaP}

Turning from overall employment effects of technology to its impact on different skill categories within labor, SBTC can be viewed as the "technology-based" explanation for the widening gap between demand for skilled and unskilled labor and the growing wage inequality between them.

An earlier stream of literature follows the more traditional "trade-based" approach to explain this phenomenon. It relies on the Heckscher-Ohlin (HO) and the Stolper-Samuelson (SS) trade theorems, and postulates that international trade and FDI are the main drivers for splitting labor demand between the skilled and unskilled workers. In particular, HO-SS predicts that tradeliberalization will reduce inequality in DCs since they would be specializing in the production and export of unskilled-labor intensive goods, given that unskilled labor is the abundant factor in those countries; this will in turn raise the real income of the unskilled labor there (Davis and Mishra, 2007). However, the HOSS predictions are not consistent with empirical evidence from DCs, where trade liberalization was coupled with increased levels of wage inequality (see for example, Wood, 2000; Slaughter, 1999).

In fact, several extensions were made to the basic HOSS model, which attempted to relax some of its more restrictive assumptions and allow it to operate in a more realistic framework. Wood (1994)

will not create substantial employment in the technology supplier sectors. The compensation mechanism through decrease in wages might also be ineffective in developing countries since wages there are already low. Therefore, the expectation that reduction in wages will help in increasing labor demand is not valid in the case of developing countries.

${ }^{2}$ Empirical studies supporting SBTC were conducted for several other countries like the UK (see Machin 1996, Heskel and Heden,1999), France (see Mairesse, Greenan, and Topiol-Besaid, 2001, Goux and Maurin, 2000), Germany (see Falk and Seim,1999), Italy(see Piva and Vivarelli, 2002), and Spain( see Aguirregabiria and Alonso-Borrego, 2001). 
divided workers into three categories: non-educated, basic educated and skilled workers, which allowed for observing different within-country inequality trends resulting from international trade, especially in low and middle income countries. Davis (1996) extended the analysis from a NorthSouth framework into several country groups, or "cones of diversification", where the direction of trade flows among countries determined the final distributional outcome. Dornbusch, Fischer and Samuelson (1980) proposed a model with a continuum of goods that are ranked according to their relative capital intensity, which enabled them to study the changes in prices and wages within the country. Finally, Feenstra and Hanson (1996) brought intermediate goods and outsourcing activities into the analysis, and argued that moving non-skill intensive productions abroad leads to a shift in employment towards more skilled workers within local industries. The main conclusion of these departures from the standard HOSS framework is that international trade may lead to different within-country inequality trends, especially in low and middle-income countries, that are not consistent with the predictions of HOSS. However - despite the changes that these models introduced - they remained to operate within the same HOSS framework, where returns to factors of production are conditional on their relative distribution among countries (Arbache, 2001) and where technology is assumed homogeneous across countries.

\subsection{Technological Change in Developing Countries}

Indeed, one of the main restrictions of the HOSS theory is the assumption that all countries have identical levels of technology and so analyses within this framework do not allow for studying the dynamic effects of trade. The SBTC approach makes this drastic break from HOSS and drops the assumption of technological homogeneity among countries. This in turn allows for the assessment of the effect of technology transfer in developing countries on their levels of inequality (Acemoglu, 1998) as well as the changing structure and composition of their labor markets.

A standard assumption is that the developed countries have higher levels of technology than developing countries, with trade openness acting as a catalyst for the transfer of technology from the more developed to the less developed nations. Even though developed countries do not usually transfer their best state-of-the-art technologies, it remains safe to assume that they do bring about significant relative upgrading to the traditional modes of production of local industries in DCs. Therefore, the final employment impact of trade would be highly dependent on the skill-intensity embodied in the transferred technology. Since R\&D activities are generally quite limited in DCs, trade liberalization plays a crucial role in opening the door to various channels of technology transfer, which act as the primary means of technological upgrading in these countries.

The fact that DCs rely on importing technology from developed countries through the channels of trade and FDI has given rise to the hypothesis of skill-enhancing trade (SET), which was first proposed by Robbins (1996 and 2003). In particular, DCs' imports mainly consist of capital goods which embody technologies that are surely more advanced and skill-biased than those originally used in the local economies. Moreover, in those DCs that are shifting from import-substitution economic systems to trade liberalization systems, strategies that hampered the adoption of foreign technologies no longer exist, and increased market competition leads to an increased adoption of modern, skill-intensive technologies. Consequently, the liberalized DCs appear to follow a skill- 
intensive biased trend similar to that being observed in developed countries (see Robbins 1996; Berman and Machin, 2000 and 2004).

Beyond the skill enhancing effect that technology transfer might induce, the final outcome of liberalization on overall employment cannot be determined a priori because these channels of technology transfer might set off various processes whose final balance is not clear. For instance, while exports may induce demand-led growth in output and employment, increased imports could replace previously protected domestic firms and cause labor redundancy. In addition, the lack of infrastructure, scarcity of skilled labor, under-investment and other supply constraints might cause productivity growth to exceed output growth and consequently limit job creation (Lee and Vivarelli, 2006).

An increase in the demand for skilled labor in DCs has been empirically documented and studies have found evidence in support of SBTC in these countries. This invalidates the HOSS predictions regarding the egalitarian effects of trade in those countries (Revegna, 1997). For instance, Fajnzylber and Fernandes (2009) study the effects of international integration on a cross-section of manufacturing plants in Brazil and China. They find that the use of imported inputs, exports and FDI are associated with higher demand for skilled workers in Brazil; however, the same is not true for China, where specialization in unskilled labor intensive productions turns out to compensate for the access to skill-biased technologies. A more recent paper that also takes the case of Brazil using a panel of manufacturing firms over the period of 1997 - 2005, reaches similar conclusions that support the hypothesis of skill-enhancing trade and the fact that technology has played a significant role in up-skilling manufacturing labor in Brazil (Araujo, Bogliacino, and Vivarelli, 2011). Pavcnik (2003) investigated skill upgrading in Chile for the period 1976 - 1986, but did not find significant evidence supporting SBTC. However, later research on Chile conducted by Fuentes and Gilchrist, (2005) who expanded the study period to 1995, did find a significant relation between the adoption of foreign technology and increased relative demand for skilled labor. Feenstra and Hanson (1997) use data from Mexican industries and find a positive relation between FDI and demand for skilled labor. Hansen and Harrison (1999) further study the case of Mexico and conclude that indeed FDI, licensing agreements, and imports are all channels of technology transfer and lead to higher demand for skilled labor. Birchenall (2001) also attributes increased inequality in Colombia to SBTC resulting from trade liberalization and increased openness of the economy. Gorg and Strobl (2002) show that using technologically upgraded foreign machinery in Ghana has led to an increase in the demand for skilled labor. However, they do not find that export activity has a skill bias effect. Finally, Meschi, Taymaz and Vivarelli (2011) study the effect of trade openness on inequality in Turkey. They conclude that both imports and exports contribute to raising inequality between skilled and unskilled workers due to the skill biased nature of the technologies that are being imported and used in industries with export orientations.

Another set of studies performed analysis using cross-country data. Berman and Machin (2000 and 2004) investigate SBTC in the manufacturing sectors of middle income countries. They observe that the industries that upgraded their technologies and increased their demand for skilled labor in the developing countries during the 1980s are the same industries that underwent this process in the US during the '60s and '70s; they conclude that technologies are being transferred from developed 
to developing countries where they are having the same skill-upgrading effect. Meschi and Vivarelli (2009) study the impact of trade on within-country income inequality in a sample of 70 DCs over the 1980-1999 period; their results suggest that total aggregate trade flows are weakly related with income inequality; however, once they disaggregate total trade flows according to their areas of origin/destination, they find that trade with high income countries worsens income distribution in middle income DCs, both through imports and exports. Their findings provide a preliminary support to the hypothesis that technological differentials between trading partners are important in shaping the distributive effects of trade openness. By the same token, Conte and Vivarelli (2011) report evidence of a positive relationship between the import of embodied technology and increased demand for skilled labor in low and middle-income countries. They show that the skillenhancing trade - measured through imports of industrial machinery, equipment, and ICT capital goods - plays a key role in diverging labor demand towards the more skilled and away from the unskilled. Their empirical study was based on panel data covering the manufacturing sectors of 23 low and middle-income countries over the period of 1980 - 1991. Almeida (2009) reaches similar conclusions when studying 8 countries in East Asia; however, she did not find evidence supporting SBTC in low income countries or China.

Finally, for firms in DCs, exports can be another channel for technological transfer through "learning by exporting" (Keller, 2001), which gives rise to efficiency gains and the possibility of acquiring knowledge of international best practices (Vivarelli, 2011). Moreover, foreign clients may provide their suppliers in DCs with technical assistance, and transmit to local firms some relevant expertise, in order to improve the quality of imported goods (Epifani, 2003). In terms of employment effects, Yeaple (2005) showed that exporting firms' demand for skilled labor increases because the adoption of new technologies is more profitable for them.

\section{THE DATA}

This study uses data from the Turkish "Annual Manufacturing Industry Survey" conducted by the National Turkish Statistical Institute, TurkStat. The survey covers a total of 17,462 firms for the period between 1980 and 2001. The survey includes private firms having at least 10 employees as well as public ones, representing around $90 \%$ of the Turkish manufacturing output, within the formal sector. They are classified by their type of activity according to the "International Standard Classification", ISIC Rev.2.

The database provides a wide range of information on each firm including the economic activity of the firm, its employees and their wages, the firm's purchases of input, its volume of sales and output, its investment activities, and the status of its assets and capital. All monetary variables are expressed in 1994 Turkish Lira, using sector-specific deflators.

Employment is measured as the number of workers per year. Workers are divided into two broad categories: (1) production workers, including technical personnel, foremen, supervisors and unskilled workers, and (2) administrative workers, including management and administration employees, and office personnel. This categorization is used in the empirical analysis to distinguish between white collar (skilled) workers proxied by the administrative workers, and blue collar 
(unskilled) workers proxied by the production workers. The decision to categorize skilled and unskilled labor based on this division stems from the fact that this approach has been used in literature and has shown satisfactory results (see for example, Berman, Bound and Griliches, 1994; Leamer, 1998). Although the ideal categorization for skilled and unskilled workers would be one based on educational attainment or a further disaggregation by working tasks, the adopted categorization is the only workable within our dataset. In fact, the database does contain a more detailed description of workers' tasks; however, it does not contain corresponding wage data, so it could not be used in the empirical analysis (see Section 5).

\section{DESCRIPTIVE ANALYSIS}

\subsection{STRUCTURAL AdJUSTMENT AND TRADE LIBERALIZATION IN TURKEY}

The Turkish economy achieved significantly high growth rates during the 1960s and 1970s under the import substitution (IS) industrialization strategy; however, these rates showed to be unsustainable in the late 1970's when the country fell in a severe balance of payments crisis. In 1980, Turkey launched a stabilization program, which entailed a set of policies that aimed at, as Senses (1991) explains, "changing the system of incentives from archetypal import substitution, with its heavy state intervention and widespread rent-seeking, toward export orientation with an overall emphasis on market-oriented policies".

Under the protectionist economic policies, the state represented the locomotive of the economy (Saracoglu, 1987), where vigorous public investment led to expanding the domestic production capacity in heavy manufacturing and capital goods, such as machinery, petrochemical and basic intermediates (Metin-Ozcan et al.2001). The state played a dual role of an investing and producing agent with State Economic Enterprises (SEEs) serving as the major tools for achieving the industrialization targets (Metin-Ozcan et al., 2001). Consequently, a large industrial base was established in the country, and Turkey was able to achieve significant rates of growth in the manufacturing output during the period 1965- 1980 (an annual average of 7.5 percent) (Senses, 1994).

Nonetheless, the protectionist policies had some major limitations that rendered the system unsustainable. In the mid 1970's Turkey faced deterioration in its economic environment mainly due to its failure to adjust and adapt to external changes in the world economy (such as increase in oil prices in 1974, and recession in the industrialized countries) (Saracoglu, 1987). The IS strategy began to reach its limits when financing the balance of payments and industrial investments became increasingly difficult (Metin-Ozcan et al,2001). Furthermore, pushing the pace of industrialization beyond the available resources led to serious macroeconomic instabilities (Senses, 1994). By 1979, Turkey stood in the midst of a severe foreign exchange crisis, where it was unable to import even essential items, its inflation accelerated, and unemployment was widespread (Saracoglu, 1987).

In January of 1980, Turkey launched a comprehensive structural adjustment reform program under the auspices of the IMF and the World Bank. The Stabilization and Structural Adjustment Program (SSAP) was based on an "outward oriented trade" strategy and foreign trade, where product, and 
later, capital markets were liberalized to a large extent (Taymaz, 1999). The new program abolished import substitution as the major strategy for economic growth (Saracoglu, 1987) and firmly established a new regime centered on an export-led growth strategy (Taymaz, 1999).

The first phase of structural adjustment operated under the grand title of export promotion, but still under a regulated foreign exchange system and controls over capital inflows. Integration with world market during this phase was realized mainly through commodity trade liberalization (Boratav et al, 2001) ${ }^{3}$. This phase however witnessed severe erosion of wage incomes through hostile measures against organized labor. The restraint of wages played a significant role in lowering production costs and squeezing the domestic absorption capacity (Metin-Ozcan, et al, 2004). This mode of surplus creation reached its economic and political limits by 1988, and as a result, financial markets were completely deregulated (Boratav et al, 2001). The country opened up its domestic and asset markets to international competition with the declaration of the convertibility of the Turkish Lira in 1989 (Boratav et al., 2001). In 1996 Turkey signed the Custom Union agreement with the European Union (EU) ${ }^{4}$. It also endorsed Free Trade Agreements (FTAs) with the European Free Trade countries, Central and Eastern European countries, and Israel. These changes led to significant increases in both imports and exports (see figure 1 below). The import penetration ratio for manufacturing increased from 15 percent in 1980 to 22 percent in 1984 and continued to fluctuate around this rate during the 90 s to reach $30 \%$ in 2000 (Taymaz and Yilmaz, 2007). The export to output ratio in the manufacturing sector increased from about $16 \%$ in 1984 to $20 \%$ in 1989 and exceeded $30 \%$ in the year 2000 .

Figure 1: Trade volumes in Bil. USD



Source : TurkStat, Foreign Trade Statistics

\footnotetext{
${ }^{3}$ In the period between 1980 and 1983, the major reform emphasis was on encouraging exports through export tax rebates, preferential export credits, foreign exchange allocation, and duty-free access to imports (Taymaz and Yilmaz, 2007). During this period, the total subsidy rate received by manufactured goods exporters reached 20-23 percent (Milanovic, 1986). The subsidies were particularly high for exports channeled through foreign trade companies (Celasun, 1994). Later, after 1984 the import regime underwent fundamental reforms, where a large number of commodities were allowed to be imported without any prior permission and quantitative restrictions were eliminated (Taymaz and Yilmaz, 2007).
}

4 This agreement entailed the free circulation of all industrial goods between EU and Turkey. In addition, Turkey adopted the EU's common external tariff for industrial products and the industrial elements of processed agricultural products. 
The levels of FDI also increase dramatically with the opening of the country. As Figure 2 below shows, FDI levels were low during the 1970s, i.e. before the launching of the SSAP, and began to increase during the 1980s to surge in 1989 with the full liberalization of capital accounts.

Figure 2: FDI inflows

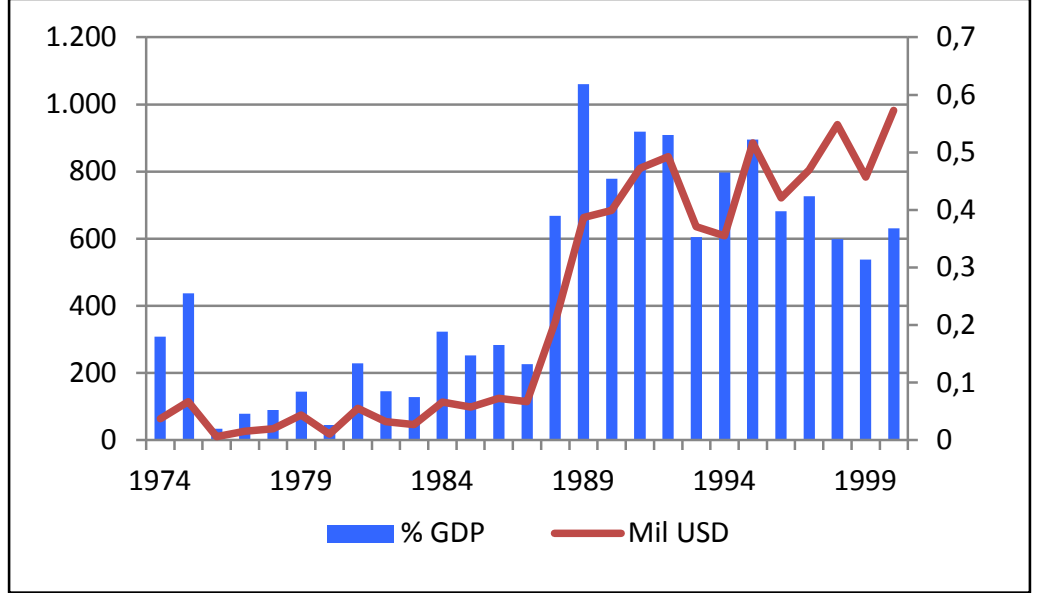

Source : World Development Indicators / The World Bank

\subsection{EMPLOYMENT IN THE MANUFACTURING SECTOR}

There has been a continuous significant shift of the Turkish workforce away from agriculture and into the services sector in the first place, followed by industry and construction. The share of workforce in the industrial sector has increased from 14\% in 1975 to $18 \%$ in 2000 (Tunali, 2003). Looking at the structure of manufacturing labor force in more detail through our data, we can observe that overall employment has been increasing for both production and administrative workers (Fig.3). Production workers seem to face higher fluctuations while the increase in administrative workers has been fairly steady. The average ratio of administrative to production workers is 0.27 over the period 1980-2001, where it was 0.25 in 1980 and reached 0.28 in 2001. 
Figure 3: Employment of production and admin workers

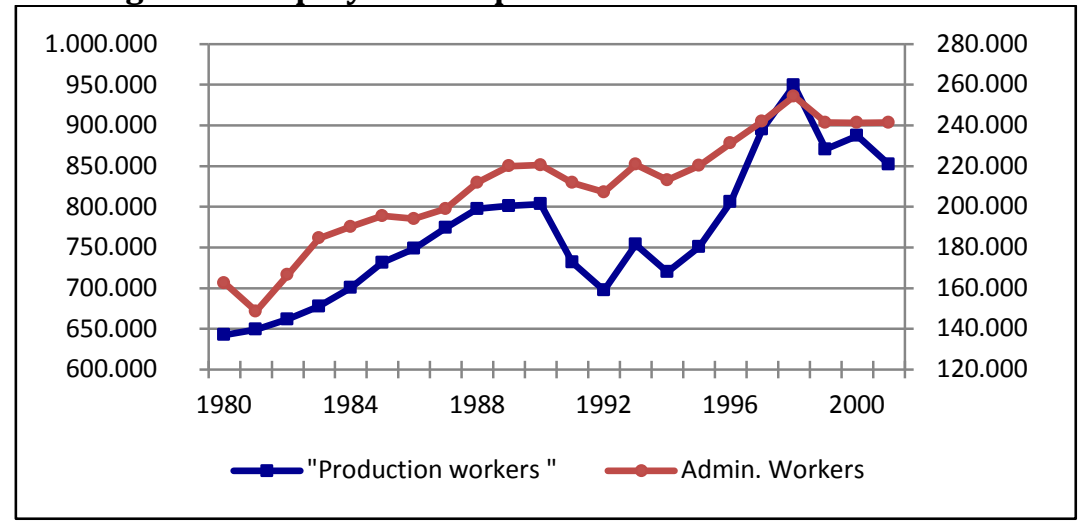

Source: Own elaborations from Annual Manufacturing Industry Survey, TurkStat

\subsection{TEChNOLOGicAl UPGRADING IN TURKEY}

Although Turkey enjoys a relatively dynamic and active manufacturing sector relatively to other DCs, the intensity of R\&D activities remains low. Figure 4 below shows the gross domestic expenditure on R\&D to GDP ratio. The ratio has been improving, with fluctuations, over time; however, it continues to fall much lower than the OECD average.

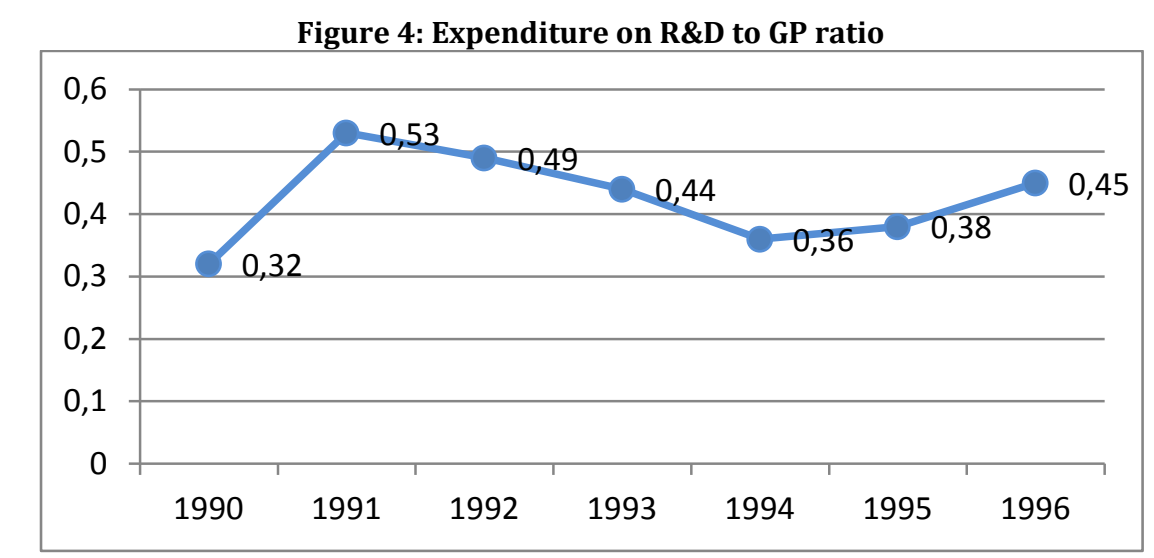

Source: Elci, 2003. "Innovation Policy in Seven Candidate Countries". ADE, March 2003

Although the business sector's share of funding R\&D had increased from $27 \%$ in 1990 to $42 \%$ in 1999, it continued to be lower than the OECD average of 63\% (Pamukcu, 2003). The largest portion of businesses spending on R\&D are within the manufacturing sector: 92\% in 1995 (Erdilek, 2005). The government remains to fund more than half R\&D expenditure in the country, and most of public funded R\&D activities are performed in universities (Pamukcu, 2003). In fact, around two thirds of R\&D in Turkey is produced by higher education institutions (Erdilek, 2005), which raises concerns about the actual benefit of these research activities for the business sector. Indeed, Pack 
(2000) points out that government-funded institutions in DCs often tend favor self-sufficiency in technology generation at the expense of technology imports that remain essential for industrial development in these countries. Table 1 below shows the total share of firms who perform R\&D in the manufacturing sector, as well as the share of private and public firms. The share of public R\&D performers remains higher than that of private performers, namely due to the fact that most R\&D funding is public.

Table 1: R\&D performers in the Turkish manufacturing sector

\begin{tabular}{|cccc|}
\hline Year & $\begin{array}{c}\text { total R\&D } \\
\text { performing firms }\end{array}$ & $\begin{array}{c}\text { private R\&D } \\
\text { performers }\end{array}$ & $\begin{array}{c}\text { public R\&D } \\
\text { performers }\end{array}$ \\
\hline $\mathbf{1 9 9 2}$ & $8.3 \%$ & $8.1 \%$ & $14.8 \%$ \\
\hline $\mathbf{1 9 9 3}$ & $12.5 \%$ & $12.4 \%$ & $14.4 \%$ \\
\hline $\mathbf{1 9 9 4}$ & $14.8 \%$ & $14.8 \%$ & $15.0 \%$ \\
\hline $\mathbf{1 9 9 5}$ & $16.0 \%$ & $15.9 \%$ & $18.2 \%$ \\
\hline $\mathbf{1 9 9 6}$ & $13.9 \%$ & $13.9 \%$ & $16.0 \%$ \\
\hline $\mathbf{1 9 9 7}$ & $13.3 \%$ & $13.2 \%$ & $15.8 \%$ \\
\hline $\mathbf{1 9 9 8}$ & $13.6 \%$ & $13.5 \%$ & $19.7 \%$ \\
\hline $\mathbf{1 9 9 9}$ & $14.5 \%$ & $14.4 \%$ & $19.3 \%$ \\
\hline $\mathbf{2 0 0 0}$ & $15.1 \%$ & $14.8 \%$ & $26.2 \%$ \\
\hline $\mathbf{2 0 0 1}$ & $12.1 \%$ & $11.9 \%$ & $21.3 \%$ \\
\hline
\end{tabular}

Source: Own elaborations from Annual Manufacturing Industry Survey, TurkStat

The establishment of the Technology Development Foundation of Turkey (TTGV) in 1991 and the launching of R\&D support programs in the 1990s formed a major step towards institutionalizing innovation activities in Turkey ${ }^{5}$. A study on the effectiveness of these public support systems (Ozcelik and Taymaz, 2008) showed that public R\&D support tends to also stimulate private R\&D activities, especially within smaller firms.

On the whole, we can conclude that technological upgrading in Turkey is likely to be mainly implemented through imported capital goods; nevertheless, the domestic R\&D activities are not negligible and should be taken into account in the following empirical analysis (see next section).

\footnotetext{
5 The Technology Development Foundation of Turkey provides R\&D support in the form of interest-free "R\&D loans" since 1992. The Technology Monitoring and Evaluation Board of the Scientific and Technical Research Council of Turkey (TIDEB of TUBITAK, in Turkish acronyms) is the other major R\&D supporter in Turkey. R\&D support rate depends the share of the products (produced through R\&D) in total sales, employment of $\mathrm{PhD}$ researchers, R\&D services obtained from universities, R\&Dperformed within techno-parks, and projects undertaken in priority areas, among other factors (Ozcelik and Taymaz, 2003).
} 


\section{THE EMPIRICAL MODEL}

\subsection{MODEL SPECIFICATION}

Consistently with the previous empirical literature studying the employment effects of technological change and assuming a perfect competition setting (see Van Reenen, 1997), the labor demand equation is derived using a constant elasticity of substitution (CES) production function of the following form:

$$
\mathrm{Y}=\mathrm{T}\left[(\mathrm{AL})^{\sigma-1 / \sigma}+(\mathrm{BK})^{\sigma-1 / \sigma}\right]^{\sigma / \sigma-1}
$$

where $\mathrm{Y}$ is output, $\mathrm{L}$ and $\mathrm{K}$ are the standard inputs of labor and capital respectively; $\mathrm{T}$ is a Hicksneutral technology parameter (movements in $\mathrm{T}$ leave the capital-labor ratio constant), $\mathrm{A}$ is labor augmenting Harrod-neutral technology, and B is capital augmenting Solow-neutral technical change. By setting real wages equal to the marginal productivity of labor, the following first order condition equation for labor is obtained.

$$
\ln L=\ln Y-\sigma \ln (W)+(\sigma-1) \ln A
$$

Since the present model separates between blue-collar and white-collar workers, the above equation can be expressed for each labor category separately.

$$
\begin{aligned}
& \ln B C=\ln Y-\sigma_{B C} \ln (B C W)+\left(\sigma_{B C}-1\right) \ln A_{B C} \\
& \ln W C=\ln Y-\sigma_{W C} \ln (W C W)+\left(\sigma_{W C}-1\right) \ln A_{W C}
\end{aligned}
$$

where WCW and BCW are the real wages for white-collar and blue-collar workers respectively. Costs of labor adjustments call for transforming the model from a static to a dynamic one, in order to take into account firm's attrition and delays in hiring/firing workers (see Lachenmaier and Rottman, 2011); therefore, a lagged employment variable is added to the equations. Moreover, the specification is extended to include proxies for the various factors related to trade and technology. The final estimating equations are the following:

$$
\mathrm{BC}_{\mathrm{it}}=\alpha+\beta \mathrm{BC}_{\mathrm{it}-1}+\delta \mathrm{BCW}_{\mathrm{it}}+\gamma \mathrm{Y}_{\mathrm{it}}+\eta \mathrm{TECH}_{\mathrm{it}}+\mu \mathrm{EXP}_{\mathrm{t}}+\lambda \mathrm{INV}_{\mathrm{it}}+\left(\mathrm{u}_{\mathrm{it}}+\varepsilon_{\mathrm{i}}\right)
$$




$$
\mathrm{WC}_{\mathrm{it}}=\alpha+\beta \mathrm{WC}_{\mathrm{it}-1}+\delta \mathrm{WCW}_{\mathrm{it}}+\gamma \mathrm{Y}_{\mathrm{it}}+\eta \mathrm{TECH}_{\mathrm{it}}+\mu \mathrm{EXP}_{\mathrm{it}}+\lambda \mathrm{INV}_{\mathrm{it}}+\left(\mathrm{u}_{\mathrm{it}}+\varepsilon_{\mathrm{i}}\right)
$$

All variables are expressed in natural logarithms. BC and WC are respectively the numbers of bluecollar and white-collar workers of sector $i$ at time $t$. BCW and WCW are the wages of each labor category. $\mathrm{Y}$ is the output variable that reflects the impact of firms' sales and also controls for possible business cycle fluctuations that can affect demand for the different types of labor. TECH is a vector composed of two dummy variables representing domestic and imported technology: namely, the presence of internal R\&D expenditures (R\&D) and the obtained availability of a foreign patent or other appropriability devices developed abroad (PAT). EXP is a dummy that takes the value of one when the firm is an exporter and zero if it does not export. INV represents firms' net investment. Finally, standard to panel data analysis, the error term is composed by the idiosyncratic error component $\left(\mathrm{u}_{\mathrm{it}}\right)$ and the time invariant firm fixed effect component $\left(\varepsilon_{\mathrm{i}}\right)$.

Therefore, equations (5) and (6) can be seen as a twofold dynamic labor demand, where employment depends on output, investment and wages as traditionally assumed, but also on additional drivers such as domestic technology, imported technology and "learning by export".

The most commonly used method for studying the skill employment gap is through estimating a sole relative demand for labor equation, where changes in the share of skilled workers would provide evidence for the existence of an up-skilling trend within the labor force. However, this oneequation setting does not permit the researcher to go a step further into investigating the relative versus absolute skill bias. Indeed, the advantage of the present two-equation setting is that is allows for this type of analysis, whereby absolute skill bias would manifest itself when the considered variables have a positive coefficient for the skilled workers and a negative coefficient for the unskilled workers, while relative skill bias would appear when the coefficients for both skilled and unskilled workers are positive but differ in statistical significance and/or in magnitude, with the coefficients for the unskilled workers being less significant and/or lower. In addition, this setting is more accurate in exploring the autoregressive dynamics of blue collar sand white collars workers separately.

\subsection{ECONOMETRIC ISSUES}

The presence of firm-specific effects creates a correlation between the lagged dependent variable $\mathrm{BC}_{\mathrm{it}-1}\left(\right.$ and $\mathrm{WC}_{\mathrm{it}-1}$ ) and the individual fixed effect $\mathrm{u}_{\mathrm{i}}$. Therefore, the dynamic specification implies a violation of the assumption of strict exogeneity of the estimators. In this context, the use of least squares will lead to inconsistent and upwardly biased estimates for the coefficient of the lagged dependent variable (Hsiao, 1986). The firm effects can be eliminated through the within-group estimator (or fixed effects estimator, FE). However, this leads to a downward bias of the estimated parameter of the lagged dependent variable (Nickell, 1981).

Extensive econometric research has been done in order to obtain consistent and efficient estimators of the parameters in dynamic panel models. Almost all approaches include first transforming the original equations to eliminate the fixed effects and then applying instrumental 
variables estimations for the lagged endogenous variable (Halaby, 2004). Andersen and Hsiao (1982) developed a formulation for obtaining consistent FE-IV (fixed effects - instrumental variables) estimators by resorting to first differencing in order to eliminate the unobserved fixed effects, and then using two lags and beyond to instrument the lagged dependent variable.

Efficiency improvements have been made to the Andersen and Hsiao model through the utilization of the GMM (Generalized Method of Moments) technique. Arrellano and Bond (1991) first resorted to GMM by using an instrument matrix that includes all previous values of the lagged dependent variable, so obtaining the GMM-DIFF estimator. However, The GMM-DIFF estimator has been found to be weak when (1) there is strong persistence in the time series, and/or (2) the time dimension and time variability of the panel is small compared with its cross-section dimension and variability (Bond et al., 2001). Blundell and Bond (1998) have performed an efficiency improvement to the GMM-DIFF by using additional level moment conditions and obtaining the system GMM or GMMSYS model. Through these added moment conditions, the GMM-SYS uses all the information available in the data based on the assumption that $E\left(\Delta u_{i t} \varepsilon_{i}\right)=0$ (Blundell and Bond, 1998; Bond, 2002). Since our panel dataset is characterized by both the above conditions (1) and (2), we adopted a GMM-SYS model.

The following Table 2 lists and defines all the variables used in the estimation.

Table 2: the variables and their definitions

\begin{tabular}{ll}
\hline Variable & Definition \\
\hline BC & Number of "blue collar" employees engaged in production activities \\
WC & Number of "white collar" employees engaged in non-production activities \\
BCW & Real wages of blue collar employees \\
WCW & Real wages of white collar employees \\
Y & Real output of the firm (sales) \\
R\&D & Dummy variable for existence of R\&D activities \\
PAT & Dummy variable for obtaining foreign royalties, patents, know-how and other \\
& property rights \\
EXP & Dummy variable for export activities \\
INV & Net investment of the firm \\
& \\
\hline Source & The Annual Manufacturing Industry Survey for the Republic of Turkey, TurkStat \\
Years & Annual observations for the period 1980 - 2001 \\
\hline
\end{tabular}

\subsection{RESULTS}

Before looking into the results of the regression estimations, there are a few points to turn attention to. 
Firstly, time persistence was tested: AR (1) was computed using ordinary least squares (OLS) in levels and the obtained outcome - showing strong and highly significant persistence - does encourage the use of a GMM-SYS estimator (see Table 3).

Table 3: Time persistence test

\begin{tabular}{ccc}
\hline & $(1)$ & $(2)$ \\
& Blue collar & White collar \\
\hline AR (1) & $\begin{array}{c}0.979^{* * *} \\
(0.0005)\end{array}$ & $\begin{array}{c}0.550^{* * *} \\
\end{array}$ \\
\end{tabular}

Notes: Standard errors in brackets. ${ }^{* * *}$ Significant at $1 \%$

Secondly, the presence of a lagged dependent variable required running an OLS regression to determine the upper bound for the value of the coefficient obtained in the GMM-SYS; therefore, the values obtained for the coefficients of $\mathrm{BC}_{\mathrm{it}-1} \mathrm{WC}_{\mathrm{it}-1}$ using OLS would serve as an upper bound for the corresponding values coming out from the estimates obtained using GMM-SYS. The OLS outcomes reported in columns (1) and (2) of Table 4 below indeed show that the values of the coefficients of the endogenous variables from GMM-SYS (columns 5 and 6) are lower than those obtained from OLS. Similarly, the FE methodology (columns 3 and 4) was applied to provide a lower bound for the value of the estimated coefficient of GMM-SYS, since the fixed effects lead to downward biased results. Also in this case, GMM-SYS results are consistent with the expectations. On the whole, the comparison between GMM-SYS on the one hand and OLS and FE on the other hand is supporting the adequacy of the chosen GMM-SYS methodology.

Thirdly, we decided to insert time dummies to control for unobserved macroeconomic and cyclical shocks that may affect the variables.

Results are discussed with reference to the preferred GMM-SYS specification (columns 5 and 6 of Table 4), although they are generally consistent across the three methodologies showed in Table 4.

The positive and highly significant values of the lagged coefficients for both types of workers confirm the persistence of the employment time-series. Also consistent with our expectations, the negative values of wages are in line with the standard requirement for the relationship between wages and labor demand.

The remaining explanatory variables all show to have a statistically significant employment enhancing effect. The output variable is positive for both blue collar and white collar workers indicating that expansion of production requires higher demand for both types of labor. However, the coefficient for the white collar workers is higher than that for the blue collar workers, with a ratio of $\mathrm{BC}$ to $\mathrm{WC}$ of 0.70 , which points out the existence of a relative skill bias effect. By the same token, net investment is also positively related to both blue and white collar workers, but in a 
similar asymmetric way (here the ratio between the blue and white collars coefficients is 0.61). Coeteris paribus, increasing sales and investments accelerates the up-skilling trend in Turkish manufacturing.

Turning our attention to the focus of this study, the R\&D dummy variable (that takes the value of 1 if the firm performs R\&D activities and zero if it does not) also shows positive and significant impact on the demand for both blue and white collar workers. However, the coefficient of this variable turns out to have a much larger magnitude (in between 5 to 6 times) for the white collar workers, indicating that innovating firms tend to have a higher demand for skill.

Contrary to the R\&D variable, which is a proxy for locally developed technologies, the Patent variable was used to measure international technological transfer through foreign licenses, patent rights and other know-how. This variable takes the value of 1 if the firm has obtained such rights and zero if it has not. Positive and significant for both types of workers, again its value is much higher (more than 5 times) for white collar workers; therefore, firms that benefit from this type of imported technology are more likely to demand more skilled workers.

Therefore, our results are strongly consistent with the SBTC hypothesis: indeed, both domestic and foreign technologies foster the demand for skilled workers in Turkish manufacturing. However, the nature of this bias is that of a relative skill-bias: new technologies do not destroy jobs (so compensation is working, see Section 2.1), but they require a much higher number (from 5 to 6 times) of additional skilled rather than unskilled workers.

The last variable studied in the regression model is the export dummy variable, taking the value of 1 if the firm performs export activities and zero otherwise. As discussed in Section 2.3, the possible skill-biased impact of this variable may be related to the so-called "learning by exporting" effect. Indeed, our results support this hypothesis, with the dummy showing a positive and significant coefficient for both blue and white collar workers, but with a larger magnitude in the case of the white collars. Therefore, engaging in export activities also seems to encourage hiring more skilled than unskilled workers.

A number of tests were performed to test the validity of the estimated model and the robustness of the corresponding results. A Wald test ${ }^{6}$ was run to test for the overall joint significance of the independent variables: it always rejects the null hypothesis of insignificant coefficients. The Hansen test for over-identifying restrictions was also performed: the null of adequate instruments was not rejected for the case of white collar workers, but it was for the blue collar one. However, since the Hansen test may over-reject in the case of very large samples (see Blundell and Bond, 1999; Roodman, 2006), the same model was run and the Hansen test performed on a random sub-sample comprising $20 \%$ of the original data. The outcome was that the Hansen tests never rejected the null, so reassuring on the validity of the chosen instruments ${ }^{7}$. Finally, the standard Arellano and Bond (AR) tests for autocorrelation support the consistency of the adopted GMM estimators, however only after using t-3 instruments.

${ }^{6}$ It is distributed as a $\chi 2$ where the degrees of freedom equate the number of restricted coefficients.

7 Results available from the authors upon request. 
Table 4: Employment equations of blue and white collar workers

\begin{tabular}{|c|c|c|c|c|c|c|}
\hline \multirow[t]{3}{*}{ VARIABLES } & \multicolumn{2}{|c|}{ OLS } & \multicolumn{2}{|c|}{$\mathbf{F E}$} & \multicolumn{2}{|c|}{ GMM-SYS } \\
\hline & (1) & $(2)$ & (3) & (4) & (5) & (6) \\
\hline & Blue Collar & White collar & Blue Collar & White collar & Blue Collar & White collar \\
\hline \multirow[t]{2}{*}{ Constant } & $-0.0333^{* * *}$ & $-0.638 * * *$ & $0.332^{* * *}$ & $0.363^{* * *}$ & -0.0297 & $-0.939 * * *$ \\
\hline & $(0.01060)$ & $(0.01530)$ & $(0.02690)$ & $(0.03480)$ & $(0.02370)$ & $(0.09610)$ \\
\hline \multirow[t]{2}{*}{ Lagged Employment BC } & $0.849^{* * *}$ & & $0.401^{* * *}$ & & $0.716^{* * *}$ & \\
\hline & $(0.00164)$ & & $(0.00322)$ & & $(0.02670)$ & \\
\hline \multirow[t]{2}{*}{ BC Wages } & $-0.0940^{* * *}$ & & $-0.131^{* * *}$ & & $-0.139 * * *$ & \\
\hline & $(0.00233)$ & & $(0.00346)$ & & $(0.00507)$ & \\
\hline \multirow[t]{2}{*}{ Lagged Employment WC } & & $0.718^{* * *}$ & & $0.263^{* * *}$ & & $0.579 * * *$ \\
\hline & & $(0.00207)$ & & $(0.00329)$ & & $(0.02770)$ \\
\hline \multirow[t]{2}{*}{ WC Wages } & & $-0.0712^{* * *}$ & & $-0.178^{* * *}$ & & $-0.112^{* * *}$ \\
\hline & & $(0.00244)$ & & $(0.00325)$ & & $(0.00569)$ \\
\hline \multirow[t]{2}{*}{ Output } & $0.0885^{* * *}$ & $0.145^{* * *}$ & $0.222^{* * *}$ & $0.186^{* * *}$ & $0.153^{* * *}$ & $0.218^{* * *}$ \\
\hline & $(0.00113)$ & $(0.00161)$ & $(0.00232)$ & $(0.00309)$ & $(0.01070)$ & $(0.01260)$ \\
\hline \multirow[t]{2}{*}{$R \& D$} & 0.00519 & $0.0629^{* * *}$ & $0.0122^{* * *}$ & $0.0251^{* * *}$ & $0.0116^{* * *}$ & $0.0631^{* * *}$ \\
\hline & $(0.00335)$ & $(0.00456)$ & $(0.00373)$ & $(0.00492)$ & $(0.00418)$ & $(0.00647)$ \\
\hline \multirow[t]{2}{*}{ Patents } & 0.00633 & $0.133^{* * *}$ & 0.01940 & $0.0379 * *$ & $0.0400^{* * *}$ & $0.209 * * *$ \\
\hline & $(0.00826)$ & $(0.01100)$ & $(0.01370)$ & $(0.01760)$ & $(0.01440)$ & $(0.02080)$ \\
\hline \multirow[t]{2}{*}{ Net Investment } & $0.00763^{* * *}$ & $0.0105^{* * *}$ & $0.00437^{* * *}$ & $0.00689^{* * *}$ & $0.00621^{* * *}$ & $0.0101^{* * *}$ \\
\hline & $(0.00032)$ & $(0.00044)$ & $(0.00039)$ & $(0.00052)$ & $(0.00048)$ & $(0.00067)$ \\
\hline \multirow[t]{2}{*}{ Exporter } & $0.00952^{* * *}$ & $0.0214^{* * *}$ & $0.00847^{* *}$ & $0.0376^{* * *}$ & $0.0287^{* * *}$ & $0.0409 * * *$ \\
\hline & $(0.00313)$ & $(0.00418)$ & $(0.00400)$ & $(0.00521)$ & $(0.00603)$ & $(0.00620)$ \\
\hline Year Dummies & Yes & yes & yes & yes & yes & yes \\
\hline Observations & 77,302 & 69,125 & 77,302 & 69,125 & 77,302 & 69,125 \\
\hline Wald test & & & & & $1194.06^{* * *}$ & $65.65^{* * *}$ \\
\hline $\operatorname{AR}(1)$ & & & & & $-22.33^{* * *}$ & $-21.65^{* * *}$ \\
\hline $\mathrm{AR}(2)$ & & & & & $2.302^{* * *}$ & $4.975^{* * *}$ \\
\hline $\mathrm{AR}(3)$ & & & & & -0.224 & 1.536 \\
\hline Hansen test & & & & & $42.33^{* * *}$ & 4.456 \\
\hline
\end{tabular}

Notes: 1. Robust standard errors in brackets.

$2 . * * *, * *$, and $*$ indicate the statistical significance at the $1 \%, 5 \%$, and $10 \%$, respectively.

Finally, since our key results depict the existence of a relative skill bias effect, the significance of the differences in the blue collars and white collars coefficients was tested (see Table 5). As can be seen, the relative skill-bias effects of both and expansionary climate and of technological advances (both domestic- and foreign-based) are strongly confirmed. In contrast, the relative skill bias impact of being an exporter is only weakly confirmed by the test. 
Table 5: $t$-statistic for comparing coefficients of the two equations

\begin{tabular}{|lll|}
\hline Variable & $\mathbf{t}-$ value & Significance level \\
\hline Output & $\mathrm{t}=3.39$ & $\rho=0.0005$ \\
\hline R\&D & $\mathrm{t}=6.69$ & $\rho=0.0005$ \\
\hline Patent & $\mathrm{t}=6.68$ & $\rho=0.0005$ \\
\hline Net Investment & $\mathrm{t}=4.72$ & $\rho=0.0005$ \\
\hline Exporter & $\mathrm{t}=1.41$ & $\rho=0.1$ \\
\hline
\end{tabular}

\section{CONCLUDING REMARKS}

This paper has empirically explored the possible roles of trade and technology in affecting the skillbased employment gap within the Turkish manufacturing sector over the two decades of the '80s and ' 90 s.

A first outcome from the study is that both technology and trade positively contributed to employment creation both within the blue and white collar workers; in other words, no negative quantitative effects are detectable as a consequence of technological change and globalization (this means that compensation does work, at least in Turkish manufacturing over the investigated period, see Section 2.1).

However, a strong evidence of a relative skill bias emerges: both domestic and imported technologies increase the demand for skilled labor from 5 to 6 times more than the corresponding demand for the unskilled labor. This evidence offers a strong support to the Skill-BiasedTechnological-Change hypothesis and points out the key role that the skill-enhancing-trade may play in shaping the demand for labor in a developing country (see Sections 2.2 and 2.3). In this context, "learning by export" also appears to have a skill biased impact, but to a lower extent.

The fact that technology and globalization imply an obvious skill-bias calls for economic policies in DCs able to couple trade liberalization (see Section 4) with education and training policies addressed to increase the supply of skilled labor. 


\section{REFERENCES}

Acemoglu, D. (1998.) Why do new technologies complement skills? Directed technical change and wage inequality. The Quarterly Journal of Economics, 113, 1055-1089.

Acemoglu, D. (2003). Patterns of skill premia. Review of Economic Studies, 70, 199-230.

Almeida, R. (2009). Openness and technological innovation in East Asia: have they increased the demand for skills?. IZA Discussion Papers N.4474, Institute for the Study of Labor (IZA), Bonn.

Anderson TW, Hsiao C. (1982). Formulation and estimation of dynamic models using panel data. Journal of Econometrics, 18, 47-82.

Ansal, K.H, \& Karaomelioglu D.C (1999). New technologies and employment: industry and firm level evidence from Turkey. New Technology, Work and Employment, 14, 82-167.

Araújo B.C., Bogliacino F., \& Vivarelli M. (2011). Technology, trade and skills in Brazil: some evidence from microdata. CEPAL Review, 105, 157-171.

Arbache, J.S. (2001). Trade liberalization and labor markets in developing countries: theory and evidences. Department of Economics Discussion Paper, N. 0112, University of Kent, UK.

Arellano, M. \& Bond, S. (1991). Some tests of specification for panel data: Monte Carlo evidence and an application to employment equations. Review of Economic Studies, 58, 277-297.

Autor, D., L. Katz, \& A. Krueger. (1998). Computing inequality: have computers changed the labor market?. Quarterly Journal of Economics, 113, 1169-1214.

Berman, E., Bound, J. \& Griliches, Z. (1994). Changes in the demand for skilled labor within U.S. manufacturing industries. Quarterly Journal of Economics, 109, 367-398.

Berman, E. \& Machin, S. (2000). Skill-Biased technology transfer around the World. Oxford Review of Economic Policy, 16, 12-22.

Berman, E. \& Machin, S. (2004). Globalization, Skill-Biased Technological Change and Labor Demand. In Lee, E. and Vivarelli, M. (Eds), Understanding Globalization, Employment and Poverty Reduction (pp. 39-66). New York: Palgrave Macmillan.

Birchenall, J.A., (2001). Income distribution, human capital and economic growth in Colombia. Journal of Development Economics, 66, 271-287.

Blundell, R. \& Bond, S. (1998). Initial conditions and moment restrictions in dynamic panel data models. Journal of Econometrics, 87, 115-43.

Blundell, R. \& Bond, S (1999). GMM Estimation with persistent panel data: an application to production functions. IFS Working Papers no. 99/04. London: Institute for Fiscal Studies

Bond, S. (2002), Dynamic panel data models: a guide to micro data methods and practice. CEMMAP Working Paper no. CWP09/02. London: Centre for Microdata Methods and Practice.

Bond, S; Hoeffler A, \& Temple, J. (2001). GMM estimation of empirical growth models. CEPR Discussion Paper no. 3048. London: Centre for Economic Policy Research.

Boratav, K., Yeldan, E. \& Köse, A.H. (2001). Globalization, distribution and social policy: Turkey, 1980-1998". In Taylor, L. (Eds), External liberalization, Economic Performance and Social Policy"(pp. 317-364). Oxford: Oxford University Press.

Conte, A. \& Vivarelli, M. (2011). Globalization and employment: imported skill biased technological 
change in developing countries. The Developing Economies, 49, 36-65.

Davis, Donald R. (1996). Trade liberalization and income distribution. NBER Working Paper no. 5693. Cambridge, Mass.: National Bureau of Economic Research.

Davis, R., \& Mishra, P. (2007). Stolper-Samuelson is dead and other crimes of both theory and data. NBER Chapters. In: Globalization and Poverty, (pp.87-10).

Dornbusch, R., Fischer S. and Samuelson P.A. (1980). Heckscher-Ohlin trade theory with a continuum of Goods. Quarterly Journal of Economics , 95, 203-24.

Elci, S. (2003). Innovation policy profile: Turkey. Enterprise Directorate-General Contract $\mathrm{N}^{\circ}$ INNO02-06. Study coordinated by ADE.

Elitok P.S., \& Straubhaar T. (2010). Turkey's globalizing economy. HWWI Policy Paper 3-13, Hamburg.

Epifani P. (2003). Trade liberalization, firm performances and labor market outcomes in the developing world, what can we learn from micro-level data?. Rivista italiana degli economisti, Società editrice il Mulino, 3, 455-486.

Erdilek, A. (2005). R\&D activities of foreign and national establishments in Turkish Manufacturing. In Blomstrom, M. Graham, E. and Moran, T. (Eds.), The Impact of Foreign Direct Investment on Development: New Measures, New Outcomes, New Policy Approaches, Institute for International Economics. Washington, DC.

Fajnzylber, P. \& Fernandes, A. (2009). International economic activities and skilled demand: evidence from Brazil and China. Applied Economics, 41, 563-577.

Feenstra, R.C. \& Hanson, G.H. (1996). Globalization, outsourcing, and wage inequality. American Economic Review, 86, 240.245.

Feenstra, R.C. \& Hanson, G.H. (1997). Foreign direct investment and relative wages: evidence from Mexico's maquiladoras. Journal of International Economics, 42, 371-393.

Fuentes, 0. \& Gilchrist S. (2005). Trade orientation and labor market evolution: evidence from Chilean plant-level data. In J. Restrepo and Tokman, A. (Eds), Labor Markets and Institutio. Central Bank of Chile, Santiago.

Griliches, Z. (1969). Capital-skill Complementarity. Review of Economics and Statistics, 51, 465-68.

Görg, H. \& Strobl, E. (2002). Relative wages, openness and skill-biased technological change. IZA Discussion Papers N. 596, Institute for the Study of Labor (IZA).

Halaby, N. C. (2004). Panel models in sociological research: theory into practice. Annual Review of Sociology, 30, 507-44.

Hanson, G. and Harrison, A. (1999). Trade and wage inequality in Mexico. Industrial and Labor Relations Review, 52, 271-288.

Hsiao, C. (1986). Analysis of panel data. New York: Cambridge University Press.

Keller, W. (2001). International technology diffusion. NBER Working Papers 8573, National Bureau of Economic Research.

Lachenmaier, S. \& Rottman, H. (2011). Effects of innovation on employment: a dynamic panel analysis. International Journal of Industrial Organization, 29, 210 -220. 
Leamer, E. (1998). In search of Stolper-Samuelson effects on US wages. In Collins, S. (Eds). Imports, Exports and the American Worker (pp. 141-214). Washington D.C.: Brookings Institution Press.

Lee, E. \& Vivarelli, M. (2006). The social impact of globalization in the developing countries. International Labor Review,145, 167-184.

Machin, S., \& J. Van Reenen. (1998). Technology and changes in skill structure: evidence from seven OECD countries. Quarterly Journal of Economics, 113, 1215-44.

Machin, D. (2003). The changing nature of labor demand in the new economy and skill-biased technology change. Oxford Bulletin of Economics \& Statistics, 63-S1, 753-776.

Marx, K. (1961). Capital. (First edition 1867). Moscow: Foreign Languages Publishing House.

Metin-Ozcan, K., E. Voyvoda, \& E. Yeldan. (2001). Dynamics of macroeconomic adjustment in a globalized developing economy: growth, accumulation, and distribution, Turkey 1969-1998. Canadian Journal of Development Studies, 22, 219-253.

Meschi, E. \& Vivarelli, M. (2009). Trade and income inequality in developing countries. World Development, 37, 287-302.

Meschi E., Taymaz E., \& Vivarelli, M. (2011). Trade, technology and skills: evidence from Turkish microdata, Labour Economics, 18, S60-S70.

Nickell, S. (1981). Biases in dynamic models with fixed effects. Econometrica, 49, 1417-1426.

Ozcelik, E. \& Taymaz, E. (2008). R\&D support programs in developing countries: the Turkish experience. Research Policy, 37 , 258-275.

Pack, H. (2000). Research and development in the industrial development process. In L. Kim, \& R. R. Nelson (Eds.), Technology, learning and innovation. Experiences of newly industrializing economies. Cambridge: Cambridge University Press.

Pamukcu, T. (2003). Trade liberalization and innovation decisions of firms: lessons from post-1980 Turkey. World Development, 31, 1443-1458.

Pavcnik, N. (2003). What explains skill upgrading in less developed countries?. Journal of Development Economics, 71, 311-328.

Pianta, M. (2005). Innovation and Employment. In J. Fagerberg, D. Mowery and R. Nelson (Eds), Handbook of Innovation (Chapter 22). Oxford: Oxford University Press.

Revenga, Ana. (1997). Employment and wage effects of trade liberalization: the case of Mexican manufacturing. Journal of Labor Economics 15 , part 2, S20-S43.

Robbins, D. (1996). HOS hits facts: facts win; evidence on trade and wages in the developing World. OECD Technical Paper No. 119.

Robbins, D. (2003). The impact of trade liberalization upon inequality in developing countries: a review of theory and evidence. Working Paper no. 13. Geneva: International Labor Organization.

Rodrik, D. (1995). Trade strategy, investment and exports: another look at East Asia. NBER Working Paper, No. 5339, Cambridge, MA.

Roodman D. (2006). How to Do xtabond2: An Introduction to "Difference" and "System" GMM in Stata. Working Papers 103, Center for Global Development.

Saracoglu, R. (1987). Economic stabilization and structural adjustment: the case of Turkey. In V. Gorbo, M. Goldstein, and M. Khan (Eds.), Growth-oriented Adjustment Programmes. the International Monetary Fund and the World Bank. 
Senses, F. (1991). Turkey's Stabilization and Structural Adjustment Program in Retrospect and Prospect. The Developing Economics, 29, 210-234.

Senses, F. (1994). The stabilization and Structural Adjustment Program and the Process of Turkish Industrialization: Main Policies and their Impact. In Senses (Eds.). Recent industrialization experience of Turkey in a global context (pp. 51-73). London: Westport CT. Greenwood Press.

Slaughter M.J. (1998). What are the results of product-price studies and what can we learn from their differences? NBER Working Papers 6591.

Taymaz E. (1999). Trade liberalization and employment generation: the experience of Turkey in the 1980's. In A. Revenga (eds), Turkey: Economic Reforms, Living Standards, and Social Welfare Study, vol. 2 Technical Papers, Washington D.C : World Bank, 1998.

Taymaz E., \& Yilmaz K. (2007). Productivity and trade orientation: Turkish manufacturing industry before and after the customs union. The Journal of International Trade and Diplomacy, 1, 127 -154.

Tunalı, I. (2003). Background study on labor market and employment in Turkey. prepared for the European Training Foundation.

Van Reenen, J. (1997). Employment and technological innovation: evidence from UK manufacturing firms. Journal of Labor Economics, 15, 255-284.

Vivarelli, M. (1995). The Economics of Technology and Employment: Theory and Empirical Evidence. Aldershot: Elgar.

Vivarelli, M. (2011): "Innovation, Employment, and Skills in Advanced and Developing Countries, A Survey of the Literature", Inter-American Development Bank, Science and Technology Division Social Sector Technical Notes, IDB-TN-351.

Vivarelli, M., 2013. Innovation and employment: the state of the art. Eurasian Business Review, forthcoming.

Welch, F. (1970). Education in production. Journal of Political Economy, 78, 35-59.

Wood, A., 1994. North-South trade, employment, and inequality: changing fortunes in a skill-driven World. Oxford: Clarendon Press.

Wood, A. (2000). Globalization and wage inequalities: a synthesis of three theories. Social Science Research Network, Working Paper No. 240458.

Yeaple, S. R., (2005). A simple model of firm heterogeneity, international trade, and wages. Journal of International Economics, 65, 1-20. 